\title{
The synthesis and application of nano doxorubicin-indocyanine green matrix metalloproteinase-responsive hydrogel in chemophototherapy for head and neck squamous cell carcinoma [Corrigendum]
}

Wang $\mathrm{H}, \mathrm{Fu} \mathrm{Z}, \mathrm{Li} \mathrm{W}$, et al. Int $J$ Nanomedicine. 2019;14:623-638.

Errors were found in several images for Figure 5F, 5G, 6A and $6 \mathrm{~B}$. The authors have advised that mistakes were made during the process of organizing the images. A lot of images were captured following immunostaining and due to the similarity of these images, several of the same images were incorrectly selected.
The authors and the editor have confirmed that the correction of the images has no significant impact on the conclusions of the study.

The authors wish to apologise for this error.

The correct artwork for each of these figures is provided below:

Figure 5F

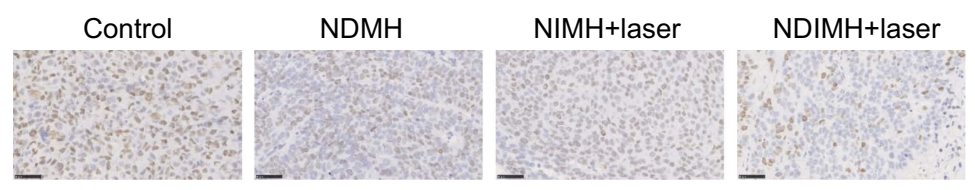

Figure 5G
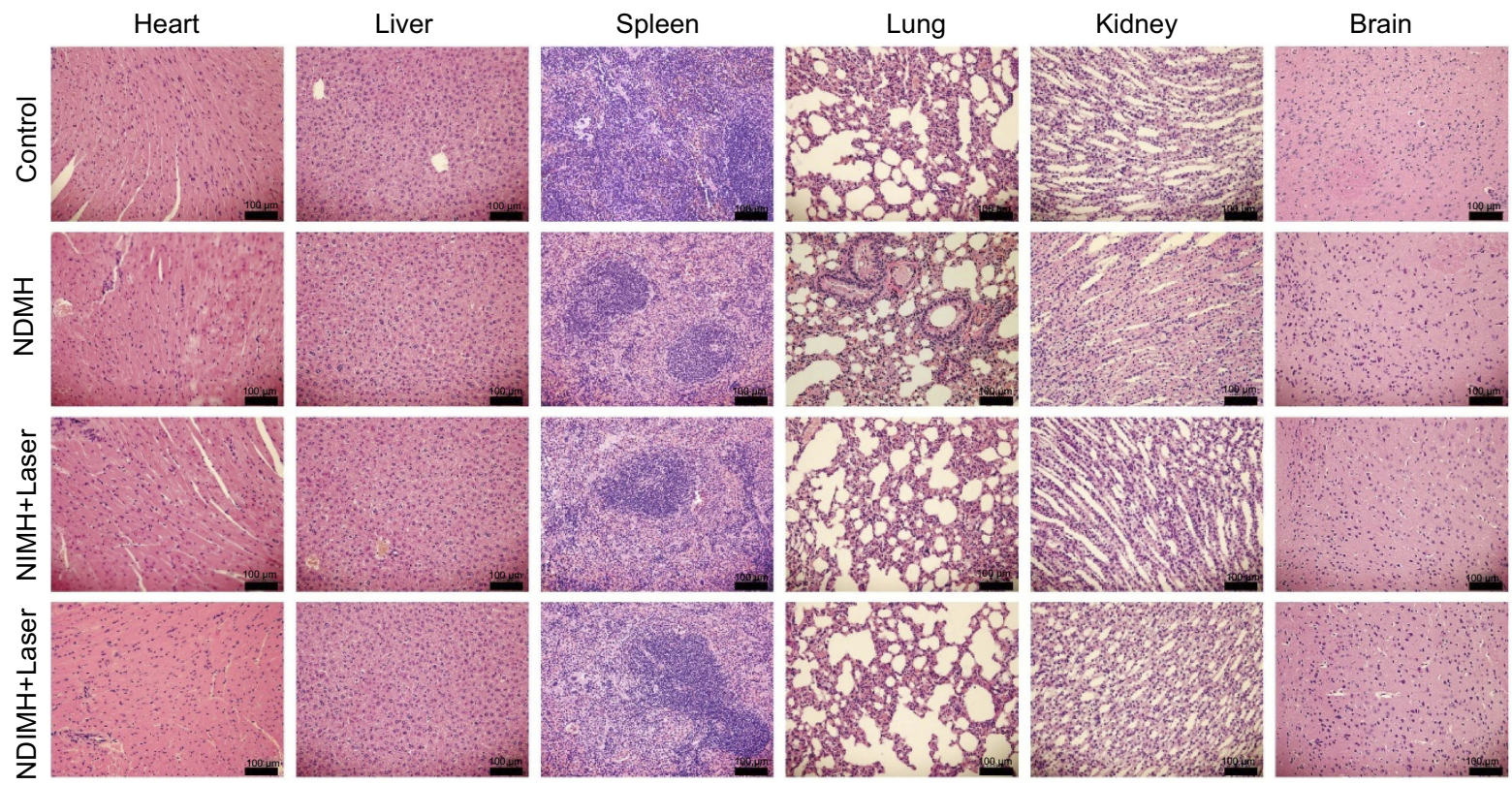
Figure 6A

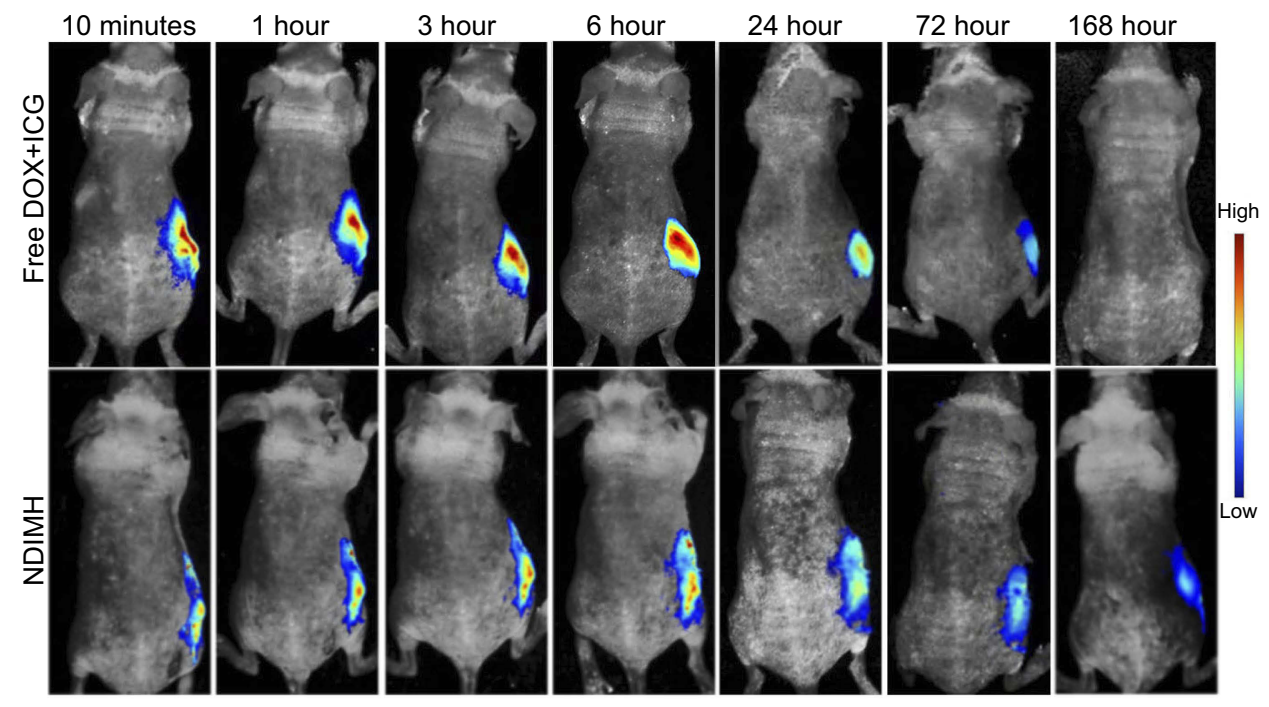

Figure 6B
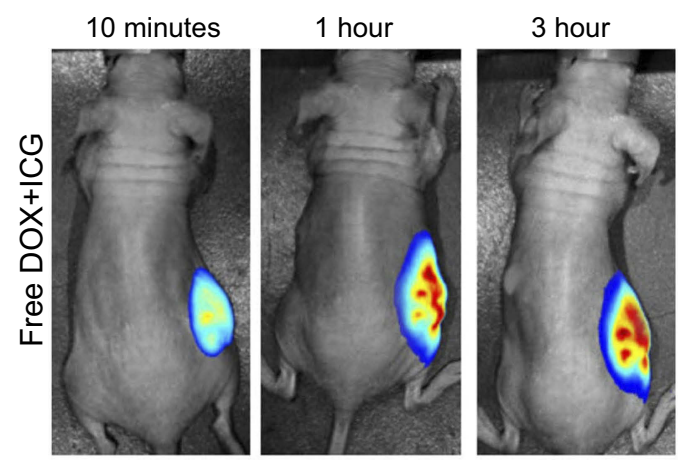

\begin{abstract}
6 hour
\end{abstract}
24 hour

72 hour

168 hour
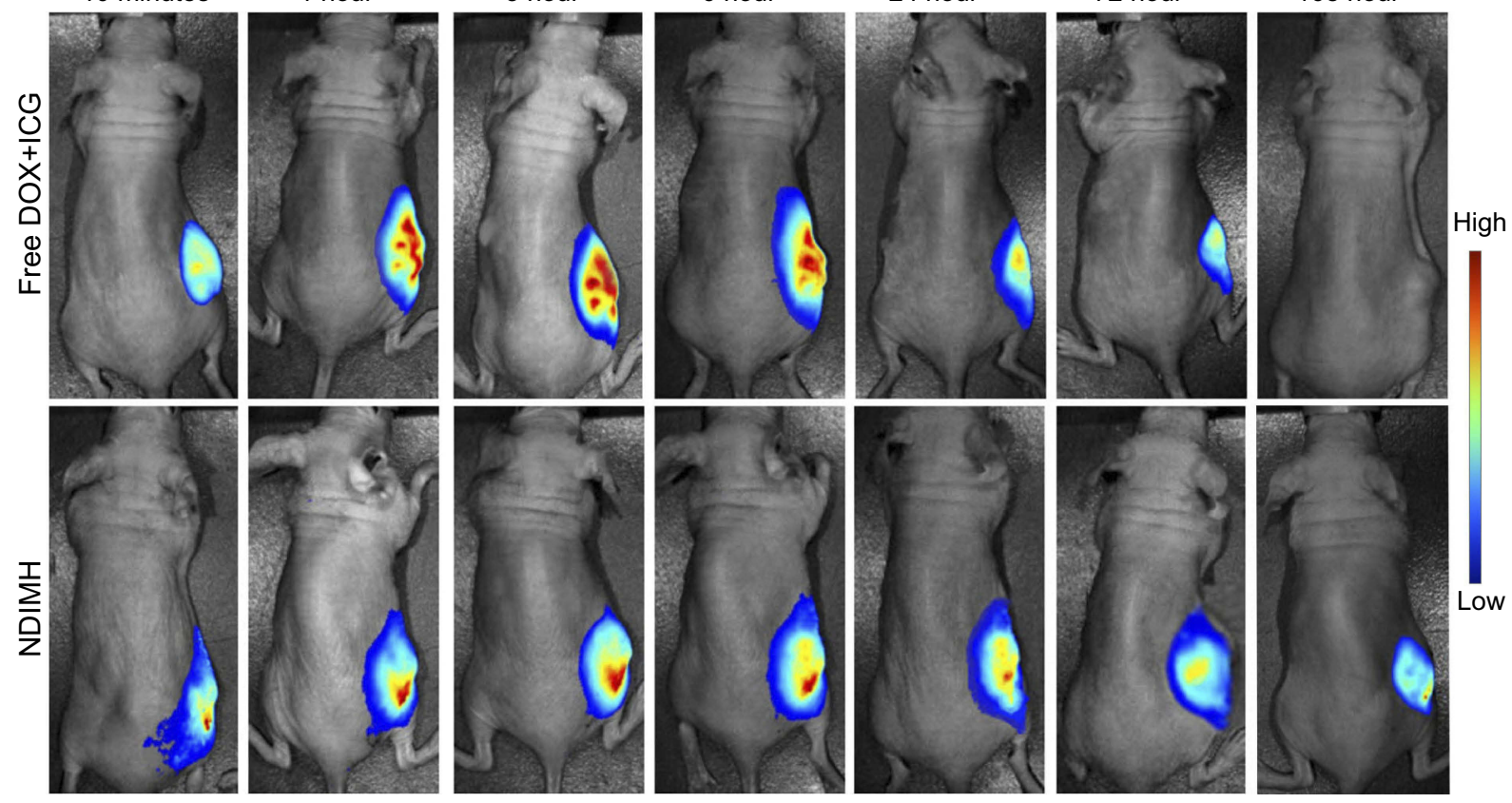

International Journal of Nanomedicine

Dovepress

\section{Publish your work in this journal}

The International Journal of Nanomedicine is an international, peerreviewed journal focusing on the application of nanotechnology in diagnostics, therapeutics, and drug delivery systems throughout the biomedical field. This journal is indexed on PubMed Central, MedLine, CAS, SciSearch ${ }^{\mathbb{B}}$, Current Contents ${ }^{\mathbb{B}} /$ Clinical Medicine, $^{2}$
Journal Citation Reports/Science Edition, EMBase, Scopus and the Elsevier Bibliographic databases. The manuscript management system is completely online and includes a very quick and fair peer-review system, which is all easy to use. Visit http://www.dovepress.com/ testimonials.php to read real quotes from published authors. 